\title{
Implementation of an Innovative Learning Resource with Project to Facilitate Active Learning to Improve Students' Performance on Chemistry
}

\author{
Manihar Situmorang ${ }^{1, *}$, Jamalum Purba ${ }^{2}$, Ramlan Silaban² \\ ${ }^{1}$ Department of Chemistry, Faculty of Mathematics and Natural Sciences, Universitas Negeri Medan, Medan, North Sumatera, \\ INDONESIA. \\ ${ }^{2}$ Department of Chemistry Education, Graduate Study Program (Program Pascasarjana), Universitas Negeri Medan, Medan, North \\ Sumatera, INDONESIA.
}

\begin{abstract}
Background: The provision of suitable and comprehensive learning resources concedes to be an effective strategy to create a serviceable learning process to achieve the competencies needed by students. Objectives: This research aims to provide an innovative learning resource with projects to facilitate active learning to improve student performance in chemistry. Methods: This research conducted by developing of chemistry learning package through the integration of projects, media and multimedia into learning materials, followed by standardization and implementation for chemistry teaching. Results: A section of an innovative learning resource with projects on the topic of Alkanes Compounds has been successfully developed. It also has been validated and standardized by experts and is considered appropriate for the teaching needs of undergraduate Chemistry and Pharmacy students. The implementation of a learning resource has proven to be beneficial in helping students to learn organic chemistry. The research findings authenticated that the developed learning resource effectively facilitates active learning in improving student performance on chemistry. The facilities available in the learning resources are sufficient to guide the students to carry out project assignments. The students are very enthusiastic about learning chemistry and their learning styles have changed to become independent learners. The developed learning resource discovered to be effective in building the skills and knowledge in chemistry. Students' performance is classified as very good, where the average score successively obtained for skills is $89.18 \pm 2.86$, the project report portfolio is $87.76 \pm 3.48$ and the formative exam is $85.84 \pm 4.46$. Conclusion: An innovative learning resource has succeeded in facilitating students' active learning, making learning more enjoyable and ultimately increasing their knowledge and skills to meet the competencies needed in the field of chemistry. Recommendation: The learning resource model developed in this study could be adopted in other subjects to facilitate active learning and to achieve the competencies needed by scientists and pharmacists.
\end{abstract}

Key words: Innovative learning, Project based learning, Students performance, Active learning, Organic chemistry.

\section{INTRODUCTION}

Improving students' performance by providing good quality learning resources is very much needed as a strategy to fulfill the life skills needed in the workforce after completing their studies. Active learning has become a trend in higher education, especially to increase the knowledge and skills needed by scientists, including pharmacists. ${ }^{1-3}$ Active learning is very appropriate to be used to build critical thinking skills and has also been proven successful in creating a more interesting learning atmosphere because it gives freedom to students to choose ways of learning that suit their needs. ${ }^{4,5}$ Active
Submission Date: 17-06-2020; Revision Date: 25-08-2020; Accepted Date: 23-10-2020

DOI: 10.5530/ijper.54.4.184 Correspondence: Prof. Manihar Situmorang Department of Chemistry, Faculty of Mathematics and Natural Sciences, Universitas Negeri Medan, Medan-20221, North

Sumatera, INDONESIA. Phone no: +62 (062)-616625970

Email id: msitumorang@ unimed.ac.id

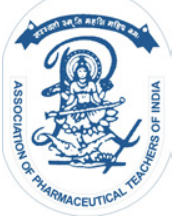

www.ijper.org 
learning has succeeded in shifting traditional teachercentered learning to student-centered learning for the achievement of competencies. ${ }^{6-8}$ However, active learning will effectively succeed in empowering students to achieve their competence if adequate learning resources are available following student development. Curriculum adjustments have been made to equip students to have the competence to overcome problems faced in the workforce. The curriculum has integrated, juxtaposed and equated the fields of science with the competencies needed in the world of work. ${ }^{9,10}$ Thus a good teaching and learning process is needed to equip students with the adequacy of knowledge, skills and attitudes needed by the world of work related to the area of expertise they learn. Various learning approaches have been chosen to chemistry teaching such as the application of teaching and learning strategies, the choice of learning media and multimedia, the application of contextual based learning, the provision of guided assignments and the application of problem-based learning (PBL). ${ }^{11-14}$ The learning approaches mentioned above have succeeded in facilitating student learning activities and creating a learning environment that encourages the formation of critical thinking. Active learning is believed to be very appropriate for teaching science, especially pharmacy. ${ }^{15,16}$

Learning innovations are very appropriate to be applied in the teaching of chemistry to provide a pleasant learning environment, facilitate students to learn optimally, make teaching and learning processes more effective and efficient and to facilitate longer memories of the chemistry material being studied. ${ }^{17-19}$ One of the learning innovations that needs attention is project-based learning $(\mathrm{PjBL}){ }^{20-22}$ The innovation of $\mathrm{PjBL}$ resources becomes a good strategy in fulfilling standard learning resources that can facilitate students to learn actively and to optimize their learning systems to fulfill the required competencies and learning outcomes. ${ }^{23,24}$ This type of learning resource is very suitable to be used in science and pharmacy teaching to facilitate active and independent learning in achieving the required competencies. Thus, providing innovative learning resources with projects becomes very interesting and challenging in the teaching of chemistry to obtain learning resource to guide students to learn systematically under the guidance or without the presence of lecturers and facilitators.

Basic organic chemistry courses become compulsory subjects for first-year science and pharmacy students. ${ }^{25-28}$ The course provides basic knowledge to study higher subjects related to living things and to understand the chemical processes associated with life. Thus, efforts must be made to provide the students to have good knowledge and skills in Organic chemistry as one of the competencies possessed by chemists and pharmacists. ${ }^{29,30}$ An innovative learning resource with the project is very appropriate to be implemented in teaching of Organic chemistry to bring the students actively participate in learning activities as the strategy to improve the knowledge and skills. ${ }^{31,32}$ Jobs in chemistry and pharmacy require special skills not possessed by other fields of study and these skills must be obtained through teaching and learning activities in classrooms, laboratories and field studies. ${ }^{33,34}$ Studying chemistry not only knows the theory but also combines it with skills. Some specific chemistry skills such as the making of solutions (weighing, dissolving and storing), handling chemical reactions (maintaining reactions and reagent conditions), skills of using laboratory equipment (designing, assembling, standardizing and troubleshooting) and the skills in conducting laboratory works (planning, implementation and reporting). All of the above skills can be mastered by students if there are sufficient innovative learning resources available to guide students to active learning. The purpose of this research is to develop and implement an innovative learning resource with projects to be used as a learning media to facilitate student active learning and at the same time to improve student performance on chemistry.

\section{Research Methodology}

\section{Population and Sample}

The study conducted at the Department of Chemistry, Faculty of Mathematics and Natural Sciences, Universitas Negeri Medan concentrated on the second semester of the academic year 2018/2019. The population and sample of this study summarized in Table 1 . There are 60 first-year students involved in the study consisted of two parallel classes with having relatively similar knowledge on Chemistry.

\begin{tabular}{|c|c|c|c|c|c|}
\hline No & $\begin{array}{l}\text { Study } \\
\text { Program }\end{array}$ & $\begin{array}{c}\text { Number } \\
\text { of } \\
\text { students }\end{array}$ & $\begin{array}{l}\text { Number } \\
\text { of } \\
\text { parallel } \\
\text { class }\end{array}$ & $\begin{array}{l}\text { Selected } \\
\text { sample } \\
\text { (Class) }\end{array}$ & $\begin{array}{c}\text { Short } \\
\text { description } \\
\text { of the Study } \\
\text { Program }\end{array}$ \\
\hline 1 & $\begin{array}{l}\text { Chemistry } \\
\text { Education }\end{array}$ & 111 & 4 & $60(2)$ & $\begin{array}{l}\text { - Major in } \\
\text { chemistry } \\
\text { education }\end{array}$ \\
\hline 2 & Chemistry & 33 & 1 & 0 & $\begin{array}{l}\text { - Major in } \\
\text { chemistry }\end{array}$ \\
\hline & Total & 144 & 5 & $93(3)$ & \\
\hline
\end{tabular}




\section{Research Methods}

This research is classified as a Research and Development for the development of innovative learning resources based on a needs analysis which is implemented to facilitate active learning students. ${ }^{35}$ The method of collecting data is using exploratory mixed methods design through the collection of respondents' opinions (Lickert scale) which are quantified into quantitative data and quantitative data in the form of students' achievements scores obtained from project report scores and formative evaluation. ${ }^{36}$

\section{Research Procedures}

The stages of the study carried out following the procedure described in the previous research with modifications. ${ }^{37}$ The procedure starts from the needs analysis stage for a learning resource of Organic chemistry, integration of projects into chemistry teaching materials, validation and standardization and implementation of learning resources for teaching Organic chemistry. The schematic of the research procedure summarized in Figure 1. The needs analysis conducted by evaluating the contents of the Alkanes compounds contained in the Organic chemistry curriculum with the competency requirements required by science undergraduate students and giving consideration to the contents of the chemistry material included in each sub-topic of Alkanes Compounds with conformity to the teaching of Basic Organic Chemistry. The next step is to compose the learning resource unit for teaching about organic chemistry by enriching the contents of chemistry materials on the subject of Alkanes Compounds to suit to the needs of first-year students. The relevant mini-project packages are integrated into each of the sub-topics of the

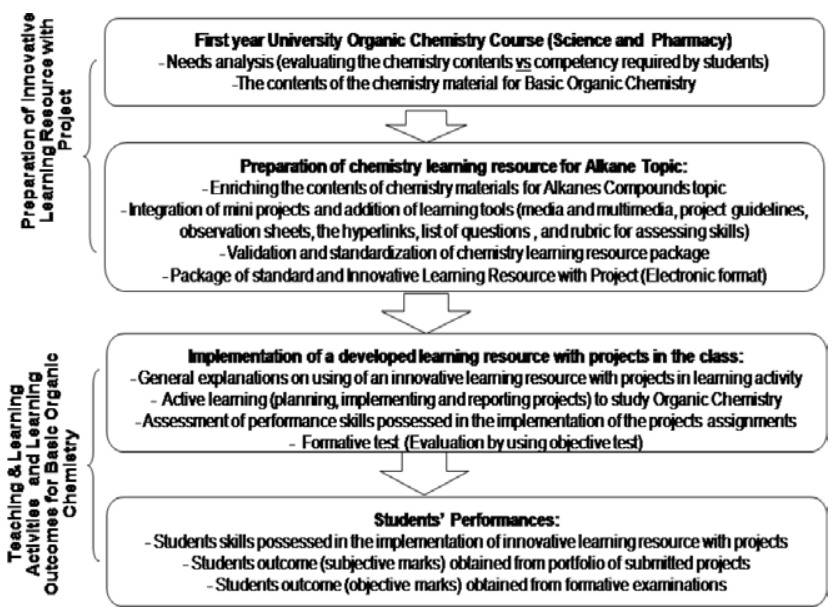

Figure 1: The stages of the research include the development of innovative learning resources and its implementation in the teaching Organic Chemistry.
Alkanes Compounds. The addition of learning tools such as media, multimedia, project implementation guidelines (i.e., starting from project planning, project implementation and reporting, providing observation sheets, compiling a list of questions to be achieved) and providing relevant and trusted hyperlinks for further studies are integrated into the package learning resources to make it compact and easy to learn. Rubrics for assessing skills and marking of project reports have also been provided. The learning unit standardized by expert validators and continued with revisions based on input from expert respondents until a standard and complete chemistry learning resource obtained. Expert respondents are Chemistry Lecturers who have had experience in teaching of Basic Organic Chemistry in tertiary institutions for at least three consecutive years, which are distributed across five Universities. An innovative project-based learning package was distributed to respondents for assessment and their opinions were asked about the quality and appropriateness of innovative learning resources for university students. The feasibility of teaching materials evaluated based on the standard criteria set by the National Education Standards Agency (NESA). Respondents' opinions on the quality of innovative learning resources assessed using a Likert scale survey question, with sequential evaluation criteria: (4) is very good, (3) is good, (2) is poor and (1) is very poor.

The implementation of innovative learning resources with a project for teaching Alkanes Compounds in the classroom exceeded to the next stage. An innovative learning package (in the form of soft copy) is distributed to students, followed by general explanations on how to use the learning resource and the stages of project implementation following the procedures provided in the learning section. Timelines for learning implementation (planning, implementing and reporting projects) and formative examinations are given to the students. Penalties applied to students who are late in submitting their project reports. Rubrics on assessing students' skills during learning activities and marking of project reports also proffered to students in order they can optimize the acquisition of learning outcomes.

Students' performance is stated based on students' completeness in the teaching-learning process that is, based on the skills possessed in the implementation of the project and the learning outcomes obtained from the project reports and the achievement score on the formative examination. Students' skills are assessed subjectively on student participation in teaching and learning activities, including the abilities in using Molymod molecular models, the ability to design and 
implement projects and the ability to answer questions according to learning targets. The assessment criteria for skills are on a score scale of 0-100. Learning outcomes recorded from the combination of the value obtained from a portfolio of project assessment reports and the learning scores obtained from the formative test at the end of the learning phase. The transcript of scores for the project is covered from average portfolio reports, which range from 0 to 100 . The evaluation score obtained from the ability to answer the objective test by giving a penalty for wrong answers and the marks converted to $0-100$.

\section{RESULTS}

\section{Description of Innovative Learning Resources with Project}

A set of innovative learning resources with projects for Organic chemistry has been developed properly under the needs of students to fulfill their competencies. There are six chemistry material for the subject of Alkanes compounds consists of six sub-subjects, namely: (1) Introduction to Alkanes, (2) The key to Functional Groups, (3) IUPAC Nomenclature and Isomers, (4) Physical Properties of Alkanes and Cycloalkanes, (5) Chemical Properties of Alkanes and Cycloalkanes and (6) Application of Alkanes Compounds. The chemistry material for each of the sub-topics has been enriched with complete chemistry contents suited to the needs of science and pharmacy undergraduate students as required by the competence curriculum. The description of sub-topics and the types of learning innovations along with the integration of projects are summarized in Table 2. The innovation is performed based on the characteristics of the sub-topics and is also adapted to the latest technological advancements with consideration to the availability of chemistry equipment, chemical reagents and supporting facilities. Project packages with multimedia project implementation are integrated into the chemistry teaching material as examples for students to plan their projects. The set of projects compiled systematically consists of the introduction, a brief theory related to the project and the reference links, materials and equipment, the schematic preparation of a complex set of equipment, project implementation steps, special attention and precaution on the handling of certain substances and materials to ensure safety in the laboratory. Observation lists and sample observation sheets, format of data collections and list of questions that must be answered through project implementation. The learning unit is with instructions for proposing a new project (application) and multimedia containing the example of a similar project that was successfully conducted.

\section{Validation and Standardization of Learning Resource}

An innovative learning resource has been validated and standardized to ensure that the quality of chemistry materials fulfilled the eligibility requirements as teaching materials for undergraduate students by the standard criteria determined by the NESA. The results summarized in Table 3. Respondents earnestly gave their opinions on all components contained in the packaging package. All parameters determining the quality of teachingmaterials such as the content, the extension, depth, design and language are assigned to be very good (average $3.72 \pm 0.44$ ). The respondents also volunteered to provide input and suggestions to improve the content of learning resources to obtain a standard teaching material. The learning resource package developed in this research has fulfilled the criteria in terms of the quality of teaching materials classified as being suitable for use as a learning resource for the teaching of undergraduate students.

\section{Learning Implementation in the Class}

An innovative learning unit with projects implemented to help the students to study Alkanes Compounds. The topic equipped with multimedia or projects, for intention to present the correct way to do the assigned project. A brief explanation given by the lecturer in the introduction remark discovered adequately to educate the students on how to use learning resources and the implementation of project assignments. Students can follow the instructions given in the learning package. Thus, it proved that the information available in learning resources is adequate, complete and easy to follow. Students succeed in establishing their projects by completing three project titles that are similar to the project format integrated into the learning resources. All students successfully adhere to the schedule set in the learning resource, which starts from proposing the project themselves, implementing the project and reporting the results of the project. All of these stages have been done through lecturer approval. The project reports submitted on time.

An innovative learning resource has been systematically structured to help students learn chemistry actively and at the same time provide skills and experiences in the field of organic chemistry. The students become skilled in handling works related to organic chemistry. Student learning independence is demonstrated through the implementation of project assignments. The skills that have been achieved by students from innovative PjBL 
Table 2: The description of innovation and integration of media or projects into Alkanes topic.

\begin{tabular}{|c|c|c|c|}
\hline No & Sub-topic & Description of innovation into chemistry material & Project Integration \\
\hline 1 & $\begin{array}{l}\text { Introduction to } \\
\text { Alkanes and } \\
\text { Cycloalkanes }\end{array}$ & $\begin{array}{l}\text { Enriching the chemistry materials for Alkanes and Cycloalkanes, the integration } \\
\text { of learning media, pictures, illustrations into chemistry topic. The learning media } \\
\text { of Moly mod molecular model to help the students to understand Alkanes topic } \\
\text { have been formulated, including for the classes of hydrocarbons: aliphatic } \\
\text { hydrocarbons and aromatic hydrocarbons. The computer simulation and the video } \\
\text { of using of Moly mod molecular model set are integrated to explain: (1) Aliphatic } \\
\text { hydrocarbons include three major groups: alkanes, alkenes and alkynes; (2) } \\
\text { Alkanes are hydrocarbons in which all the bonds are single bonds, alkenes contain } \\
\text { a carbon-carbon double bond and alkynes contain a carbon-carbon triple bond; } \\
\text { and (3) Examples of the three classes of aliphatic hydrocarbons are the two-carbon } \\
\text { compounds ethane, ethylene and acetylene }\end{array}$ & $\begin{array}{l}\text { Project 1: Classes of } \\
\text { Aliphatic hydrocarbons } \\
\text { by using Moly mod } \\
\text { molecular model } \\
\text { set and computer } \\
\text { simulation }\end{array}$ \\
\hline 2 & $\begin{array}{l}\text { The key to } \\
\text { Functional } \\
\text { Groups }\end{array}$ & $\begin{array}{l}\text { Enrichment of learning materials for functional groups, the integration of learning } \\
\text { projects for confirming the functional group. The projects is used to demonstrate } \\
\text { that a functional group is the structural unit responsible for a given molecule's } \\
\text { reactivity under a particular set of conditions. Some of the most important families } \\
\text { of organic compounds, those that contain the carbonyl group }(C=O) \text {. In this } \\
\text { projects, the student's activities in the laboratory are also included. }\end{array}$ & $\begin{array}{l}\text { Project 2: Molecule's } \\
\text { reactivity of organic } \\
\text { compounds containing } \\
\text { functional groups }\end{array}$ \\
\hline 3 & $\begin{array}{l}\text { IUPAC } \\
\text { Nomenclature } \\
\text { and Isomers }\end{array}$ & $\begin{array}{l}\text { Enrichment of chemistry materials for the topic of IUPAC Nomenclature and } \\
\text { Isomers have been carried out. The learning projects on explaining the IUPAC } \\
\text { Nomenclature are designed to make the students understand organic chemistry } \\
\text { is of two types: common (or "trivial") and systematic. The learning media to } \\
\text { demonstrate the IUPAC rules to assign compound names to unbranched alkanes } \\
\text { and highly branched Alkanes, Cycloalkanes nomenclature, the isomers and } \\
\text { naming system. The examples for IUPAC Nomenclature are provided. }\end{array}$ & $\begin{array}{l}\text { Project 3: The IUPAC } \\
\text { rules to assign Alkanes } \\
\text { and Cycloalkanes } \\
\text { compound names, } \\
\text { nomenclature and } \\
\text { isomers }\end{array}$ \\
\hline 4 & $\begin{array}{l}\text { Physical } \\
\text { Properties of } \\
\text { Alkanes and } \\
\text { Cycloalkanes }\end{array}$ & $\begin{array}{l}\text { The topic on physical properties of Alkanes and Cycloalkanes are enriched and } \\
\text { the project packages are integrated as a guidance to view the student activities to } \\
\text { related projects. The video of experimental works on boiling point, melting point } \\
\text { and solubility in water are integrated in the learning material. Handling of samples } \\
\text { are focused in the video. }\end{array}$ & $\begin{array}{l}\text { Project 4: Physical } \\
\text { properties of Alkanes } \\
\text { and Cycloalkanes }\end{array}$ \\
\hline 5 & $\begin{array}{l}\text { Chemical } \\
\text { Properties of } \\
\text { Alkanes and } \\
\text { Cycloalkanes }\end{array}$ & $\begin{array}{l}\text { The topic on chemical properties of Alkanes and Cycloalkanes are enriched and } \\
\text { the project packages, including the video are integrated in the learning material. } \\
\text { The projects packages are including Combustion of Alkanes, Heats of Combustion, } \\
\text { potential energy, Oxidation-Reduction in Organic Chemistry, Reaction of Alkanes } \\
\text { and Cycloalkanes. The students are shown how to do the right procedures on } \\
\text { doing redox reaction, including safety precaution. Handling of organic reactions are } \\
\text { focused in the video. }\end{array}$ & $\begin{array}{l}\text { Project 5: Chemical } \\
\text { properties and specific } \\
\text { reactions of Alkanes } \\
\text { and Cycloalkanes. }\end{array}$ \\
\hline 6 & $\begin{array}{l}\text { Application of } \\
\text { Alkanes and } \\
\text { Cycloalkanes } \\
\text { Compounds }\end{array}$ & $\begin{array}{l}\text { The application of alkanes compounds are integrated into learning resource } \\
\text { package. The students are given the project example on the application of alkanes } \\
\text { compounds in industry and the sources of Alkanes and Cycloalkanes in daily life. } \\
\text { Several examples of the application of alkane and cycloalkane compounds such } \\
\text { as raw materials for the chemical industry, fuel, gasoline, lubricating oil and natural } \\
\text { gas are also provided as a list that students will identify in the project. }\end{array}$ & $\begin{array}{l}\text { Project 6: Application } \\
\text { of Alkanes and } \\
\text { Cycloalkanes } \\
\text { compounds in daily life }\end{array}$ \\
\hline
\end{tabular}

are categorized to be very good (average $89.18 \pm 2.86$ ) as listed in Table 4. Students' skills in using the Moly mod molecular model are formed, especially in preparing the chemical structure of Alkanes compounds and their derivatives, determining the isomers of Alkanes compounds and naming the compounds according to the rules made by IUPAC. Students skillfully plan projects that are assigned contextually, including choosing and arranging the equipment, providing solutions and samples and constructing procedures correctly. Students' skills in taking notes, observing and reporting have also improved. Evaluation of the quality of project reports classified as good, that is, following the reporting criteria as specified in the learning resources. Students can explain their findings based on observations obtained from project implementation. Most students can discuss the results obtained by interpreting the data gained in the project reports. The ability of students to answer several questions raised at the end of each project is categorized to be very good and rational.

The implementation of innovative $\mathrm{PjBL}$ resources has changed the students learning style to shift from conventional learning (face-to-face lectures and practicum) to active learning (independent learner) that can build the knowledge and skills of chemistry. The learning outcomes summarized in Table 5. Implementation of an innovative learning resource with a project improves students' performance in chemistry. Level of student 
Table 3: Validation responses given by expert Lecturers (L) to view the quality of the developed learning resource with projects for Alkanes topic.

\begin{tabular}{|c|l|c|}
\hline No & \multicolumn{1}{|c|}{ The criteria and short description of the developed learning material } & $\begin{array}{c}\text { Respondents opinion* } \\
(\boldsymbol{M} \pm S d v), \mathrm{L}(\boldsymbol{n}=\mathbf{1 2})\end{array}$ \\
\hline 1 & $\begin{array}{l}\text { The Content: the depth, completeness and the accuracy of chemistry contents suited to the need of } \\
\text { undergraduate Chemistry and Pharmacy students. }\end{array}$ & $3.61 \pm 0.47$ \\
\hline 2 & $\begin{array}{l}\text { The Extension: Integration of projects, laboratory experiment, contextual application, multimedia, } \\
\text { learning strategy, local contents in the learning package. }\end{array}$ & $3.69 \pm 0.45$ \\
\hline 3 & $\begin{array}{l}\text { The Depth: The chemistry projects are complete and clearly derived, the topic are presented in good } \\
\text { order: introduction, main concepts, problem example, guided projects, drills, quiz and the hyperlinks } \\
\text { to trustworthy websites and the application for real life. }\end{array}$ & $3.73 \pm 0.45$ \\
\hline 4 & $\begin{array}{l}\text { The Design: The layout and the target material are suitable, the presentation of the illustrations, } \\
\text { figures, table, images are adequate and the learners are involve interactively. }\end{array}$ & $3.83 \pm 0.38$ \\
\hline 5 & $\begin{array}{l}\text { The Language: The projects are easy to read, the language is simple, the message in accordance } \\
\text { with the development of learner and scientific messages are straightforward, having accurate on the } \\
\text { typist of chemical structure, reaction and symbol and provides communicative message to readers. }\end{array}$ & $3.71 \pm 0.44$ \\
\hline & Average & $\mathbf{3 . 7 2 \pm 0 . 4 4}$ \\
\hline
\end{tabular}

*Marking criteria: 4 = very good; $3=\operatorname{good} ; 2=$ poor and 1 = very poor

Table 4: Students' performance based on the achieved skills on implementation of the projects on Alkanes topic.

\begin{tabular}{|c|c|c|c|c|c|}
\hline \multirow[t]{2}{*}{ No } & \multirow[t]{2}{*}{ Observation of on students' skills } & \multicolumn{3}{|c|}{ Students' performance (Skills)* $(M \pm S d v)$} & \multirow{2}{*}{$\begin{array}{l}\text { Performance } \\
\text { summary }\end{array}$} \\
\hline & & $\begin{array}{c}\text { Chemistry } \\
\text { Education B }\end{array}$ & $\begin{array}{c}\text { Chemistry } \\
\text { Education B }\end{array}$ & Average & \\
\hline 1 & $\begin{array}{l}\text { The students have skills to use media of Molymod molecular } \\
\text { model set to construct the structure of alkanes and cycloalkanes } \\
\text { compounds, naming the compounds correctly and to construct } \\
\text { the isomer. }\end{array}$ & $86.70 \pm 3.46$ & $88.53 \pm 3.82$ & $87.62 \pm 3.64$ & $\begin{array}{l}\text { Performance } \\
\text { achieved }\end{array}$ \\
\hline 2 & $\begin{array}{l}\text { The students are able to design their own projects related to the } \\
\text { given topics, to choose and set equipments correctly and to carry } \\
\text { out experimental steps in good order for specific projects. }\end{array}$ & $87.47 \pm 4.58$ & $89.03 \pm 3.44$ & $88.25 \pm 4.01$ & $\begin{array}{l}\text { Performance } \\
\text { achieved }\end{array}$ \\
\hline 3 & $\begin{array}{l}\text { The students are able to carry out the projects, starting from } \\
\text { planning, setting of instruments, record the results, to overcome } \\
\text { the problem in organic reactions, to prepare caution on safety } \\
\text { procedures and washing up the glass wares. }\end{array}$ & $90.50 \pm 1.53$ & $88.93 \pm 2.59$ & $89.72 \pm 2.06$ & $\begin{array}{l}\text { Performance } \\
\text { achieved }\end{array}$ \\
\hline 4 & $\begin{array}{l}\text { The students are able to finish their project on time, submitting } \\
\text { project reports followed the format given in the learning material, } \\
\text { be able to express their idea on the invention and discovery found } \\
\text { in the projects. }\end{array}$ & $86.90 \pm 2.94$ & $89.73 \pm 2.24$ & $88.32 \pm 2.59$ & $\begin{array}{l}\text { Performance } \\
\text { achieved }\end{array}$ \\
\hline 5 & $\begin{array}{l}\text { The students are able to answer the questions given in } \\
\text { the learning material related to the projects that have been } \\
\text { completed. }\end{array}$ & $91.00 \pm 1.64$ & $93.03 \pm 2.40$ & $92.02 \pm 2.02$ & $\begin{array}{l}\text { Performance } \\
\text { achieved }\end{array}$ \\
\hline & Average & $88.51 \pm 2.83$ & $89.85 \pm 2.90$ & $89.18 \pm 2.86$ & $\begin{array}{c}\text { Performance } \\
\text { achieved }\end{array}$ \\
\hline
\end{tabular}

*Obtained from subjective assessment using the rubric assessment guidelines

\begin{tabular}{l} 
Table 5: Students' performances based on students outcomes from the average marks of the portfolio of \\
submitted projects and formative test. \\
\cline { 1 - 5 } No
\end{tabular}

* Obtained from the average portfolio of submitted project reports

** Obtained from formative test 
mastery for the Alkanes topic are all classified to be very good, where the average learning outcomes from the evaluation test $(\mathrm{M}=85.84 \pm 4.46)$ and the value of project assignments $(\mathrm{M}=87.76 \pm 3.48)$. These results indicate that competency in the field of basic organic chemistry has been achieved.

\section{DISCUSSION}

An innovative learning resource package for Alkanes Compounds has been successfully developed by adopting chemistry material from several Organic Chemistry textbooks relevant to the needs of undergraduate students. ${ }^{38-40}$ The unit was containing supporting learning facilities such as media and multimedia and equipped with examples of project implementation. An innovative learning resource contains complete chemical materials for Alkanes Compounds topic accompanied by examples of projects and multimedia implementation that make it become valuable teaching material. The quality of learning resources based on the assessment of expert respondents of all components of teaching materials required by NESA is categorized very good (average 3.72 \pm 0.44 ). ${ }^{41,42}$ The developed learning resource has been compiled complete with chemistry material for undergraduate. It is suitable to be used as a learning media to build skills and enrich knowledge in chemistry. This learning resource can help students to learn organic chemistry independently. The instructions available in the learning resources have been able to guide the students to learn actively to achieve targeted learning competencies. ${ }^{43,44}$ The integration of project implementation videos in the learning package has successfully empowered the students in building the skills of handling chemicals and reagents. The completeness of the learning tools in the learning resources facilitates students to carry out the project assignments, guide the students to handle hazardous chemicals and guaranteed safety in the laboratory. ${ }^{45-47}$

Innovative learning resources with projects have been proven effective in improving student's performance, including chemical knowledge and skills. These results reinforce the results of previous studies with $\mathrm{PjBL}$ innovations. ${ }^{48}$ The developed learning resource has been proven to guide students to design their projects, train themselves to be capable in problem-solving conditions and they are also become familiarize with the discovery which has implications for meaningful learning. ${ }^{49-51}$ The chemistry studied does not only stop at the concept of theory but also involves students in constructing the relationship between theory and the practice of its application in the real world. ${ }^{52,53}$
The availability of innovative learning resource that is equipped with projects has been able to guide students to learn organic chemistry more enjoyable environment, facilitating them to construct projects assignments. In this way, the learning process becomes active and makes learning meaningful, the chemistry material learned is long remembered and can certainly improve student's performance. Students' skills can be seen from the ability of students to deal with phenomena that occur in learning chemistry related to laboratory activities. ${ }^{54,55}$ The students have demonstrated the ability to organize their learning activities ranging from planning and implementing their projects, observations to reporting are done correctly. Students have been proven able to learn independently to increase their knowledge through the use of a developed learning resource.

An innovative learning resource with projects has been proven to be very effective to improve students' competence in the field of organic chemistry. ${ }^{56}$ Students' performance can be seen from the academic scores of learning outcomes based on the portfolio of project assignment reports and from formative examinations. Students have been able to arrange the structure of organic compounds and determine isomers by using Moly mod molecular model media sets, as well as giving the names of compounds correctly. Basic knowledge of organic chemistry can be started by studying simple Alkanes compounds and their derivatives. The physical and chemical properties of organic compounds are easily studied through oxidation and reduction reactions that are implemented in project assignments. By completing the project assignments have brought the students into the real world of chemical phenomena contextually and have placed them into independent learners utilizing available learning resources. ${ }^{57-61}$ The implementation of innovative learning resources that are complemented by project examples has proven to change the way students learn organic chemistry. With this strategy, the students' performance in chemistry is assigned to be very good and the competence of chemistry is achieved. The innovative learning resources with the project becomes a good choice to empower the students to learn chemistry optimally. Therefore, the use of innovative learning resources in learning must be encouraged for other subjects in chemistry and pharmacy.

\section{CONCLUSION}

An innovative learning resource with a project has successfully been developed and implemented for the teaching of Organic chemistry. The development of learning resources carried out through the stages of needs 
analysis, enrichment of teaching materials, innovating with mini-projects and the provision of learning facilities. The learning source package was of very good quality (an average of $3.72 \pm 0.44$ ). The completeness of the learning resources had met the criteria for the needs of undergraduate science and pharmacy students. The findings of the research implementation revealed that the learning package acted effectively to facilitate student learning activities in improving performance on chemistry. An innovative learning material beneficially helps the students in carrying out laboratory activities correctly. It guides students to learn optimally in achieving their competence in the field of organic chemistry. The students demonstrated their ability in designing their projects, implementing and reporting project results. The students have achieved adequate skills in implementing project works (average of $89.18 \pm 2.86$ ). The result of the student learning outcomes from portfolio project reports classified as very good (average 85.84 \pm 4.46 ). The students have mastered organic chemistry with high marks in formative exam (average 87.76 \pm 3.48 ). The learning model reported in this study has been able to transform student learning into active and independent learners by utilizing an innovative learning resource with a project and results in improving students' performances in organic chemistry.

\section{ACKNOWLEDGEMENT}

The author acknowledges the help of Isli Iriani Pane from the Language Center of Universitas Negeri Medan, who has conducted an English proofreading process in this article.

\section{Financial Disclosure}

Research funding from Directorate of Research and Community Service, Directorate General of Research and Development Strengthening, Ministry of Research, Technology and the Higher Education Republic of Indonesia, Financial Year 2019 is acknowledged Contract No.190/SP2H/LT/DRPM/2019.

\section{CONFLICT OF INTEREST}

It is hereby stated that the author does not have a conflict of interest in the implementation of this research project

\section{ABBREVIATIONS}

NESA: National Education Standards Agency; IUPAC: International Union of Pure and Applied Chemistry;
PjBL: project-based learning, PBL: problem-based learning.

\section{REFERENCES}

1. Stewart DW, Brown SD, Clavier CW, Wyatt J. Active-learning processes used in US pharmacy education. Am J Pharm Educ. 2011;75(4):68.

2. Lucas KH, Testman JA, Hoyland MN, Kimble AM, Euler ML. Correlation between active-learning coursework and student retention of core content during advanced pharmacy practice experiences. Am J Pharm Educ. 2013;77(8):171.

3. Kennedy DR. Redesigning a Pharmacology Course to Promote Active Learning. Am J Pharm Educ. 2019;83(5):6782.

4. Styers ML, Zandt PAV, Hayden KL. Active Learning in Flipped Life Science Courses Promotes Development of Critical Thinking Skills. CBE Life Sci Educ. 2018;17(3):ar39.

5. McCoy L, Pettit RK, Kellar C, Morgan C. Tracking Active Learning in the Medical School Curriculum: A Learning-Centered Approach. J Med Educ Curric Dev. 2018;5:2382120518765135.

6. Sandrone S, Berthaud JV, Carlson C, Cios J, Dixit N, Farheen A, et al. Active Learning in Psychiatry Education: Current Practices and Future Perspectives. Front Psychiatry. 2020;11:211.

7. AlRuthia Y, Alhawas S, Alodaibi F, Almutairi L, Algasem R, Alrabiah HK, et al. The use of active learning strategies in healthcare colleges in the Middle East. BMC Med Educ. 2019;19(1):143.

8. Mesquita AR, Souza WM, Boaventura TC, Barros IM, Antoniolli AR, Silva $W B$, et al. The effect of active learning methodologies on the teaching of pharmaceutical care in a Brazilian pharmacy faculty. PLoS One. 2015;10(5):e0123141.

9. Koster A, Schalekamp T, Meijerman I. Implementation of Competency-Based Pharmacy Education (CBPE). Pharmacy. 2017 Feb 21;5(1):10.

10. Khan MO, Deimling MJ, Philip A. Medicinal chemistry and the pharmacy curriculum. Am J Pharm Educ. 2011;75(8):161.

11. Strohfeldt K, Khutoryanskaya O. Using Problem-Based Learning in a Chemistry Practical Class for Pharmacy Students and Engaging Them with Feedback. Am J Pharm Educ. 2015;79(9):141.

12. Hogan S, Lundquist LM. The impact of problem-based learning on students perceptions of preparedness for advanced pharmacy practice experiences. Am J Pharm Educ. 2006;70(4):82.

13. Rakhudu MA, Davhana-Maselesele M, Useh U. A model of collaboration for the implementation of problem-based learning in nursing education in South Africa. Curationis. 2017;40(1):e1-10.

14. Galvao TF, Silva MT, Neiva CS, Ribeiro LM, Pereira MG. Problem-based learning in pharmaceutical education: a systematic review and meta-analysis. Sci. World J. 2014;2014:578382.

15. Cooper KM, Brownell SE. Coming Out in Class: Challenges and Benefits of Active Learning in a Biology Classroom for LGBTQIA Students. CBE Life Sci Educ. 2016;15(3):ar37.

16. Steinhardt SJ, Clark JE, Kelly WN, Hill AM. Active-learning Strategies for Legal Topics and Substance Abuse in a Pharmacy Curriculum. Am J Pharm Educ. 2017;81(1):4.

17. Sadeghi R, Heshmati $H$. Innovative methods in teaching college health education course: A systematic review. J Educ Health Promot. 2019;8:103.

18. Hsiao CC, Tiao MM, Chen CC. Using interactive multimedia e-Books for learning blood cell morphology in pediatric hematology. BMC Med Educ. 2016;16(1):290.

19. McFalls M. Integration of problem-based learning and innovative technology into a self-care course. Am J Pharm Educ. 2013;77(6):127.

20. Laur D. Authentic learning experiences: A real-world approach to projectbased learning. New York, NY: Routledge. 2013.

21. Grant M. Learning, beliefs and products: Students'perspectives with projectbased learning. Interdiscip J Probl Based Learn. 2011;5(2):37-69.

22. Simaremare S, Situmorang M, Tarigan S. Innovative Learning Material with Project to Improve Students Achievement on the Teaching of AcidBase Equilibrium, Advances in Social Science. Education and Humanities Research, $3^{\text {rd }}$ Annual International Seminar on Transformative Education and Educational Leadership. 2018;200:431-6. 
23. Sinaga $M$, Situmorang $M$, Hutabarat $W$. Implementation of Innovative Learning Material to Improve Students Competence on Chemistry. Indian J Pharm Educ Res. 2019;53(1):28-41.

24. Jensen M, Mattheis A, Johnson B. Using student learning and development outcomes to evaluate a first-year undergraduate group video project. CBE Life Sci Educ. 2012;11(1):68-80.

25. Vo TH, Bedouch P, Nguyen TH, Nguyen TL, Hoang TK, Calop J, et al. Pharmacy education in Vietnam. Am J Pharm Educ. 2013;77(6):114.

26. Hirvonen J, Salminen O, Vuorensola K, Katajavuori N, Huhtala H, Atkinson J. Pharmacy Practice and Education in Finland. Pharmacy. 2019;7(1):21.

27. Gilbert JC, Martin SF. Experimental Organic Chemistry, AMiniscale and Microscale Approach. $5^{\text {th }}$ ed., Brooks/Cole, Cengage Learning, Belmont, USA. 2011.

28. Carey FA, Giuliano RM. Organic Chemistry. 8th ed McGraw-Hill, New York. 2011.

29. Richards-Babb M, Curtis R, Georgieva Z, Penn JH. Student Perceptions of Online Homework Use for Formative Assessment of Learning in Organic Chemistry. J Chem Educ. 2015;92(11):1813-9.

30. Wehle S, Decker M. Perception of the Relevance of Organic Chemistry in a German Pharmacy Students' Course. Am J Pharm Educ. 2016;80(3):40.

31. McRae MP. Correlation of preadmission organic chemistry courses and academic performance in biochemistry at a Midwest chiropractic doctoral program. J Chiropr Educ. 2010;24(1):30-4.

32. Slade MC, Raker JR, Kobilka B, Pohl NL. A Research Module for the Organic Chemistry Laboratory: Multistep Synthesis of a Fluorous Dye Molecule. J Chem Educ. 2014;91(1):126-30.

33. Volmer D, Sepp K, Raal A, Atkinson J. Pharmacy Practice and Education in Estonia. Pharmacy. 2019;7(3):87.

34. Dubey A, Ravi GS, Hebbar S, Shastry CS, Charyulu RN. Role of Communication Skill and Good Documentation Practice in the Overall Development of the Pharmacy Graduates in India: An Observational Study with Classroom Record-Daily Laboratory Record-Human Resource Record (CR-DR-HR) Model. Indian J Pharm Educ Res. 2018;52(4 Suppl 2):S158-63.

35. Kimbell R, Stables K. Researching design learning: Issues and findings from two decades of research and development. Lexington, KY: Springer. 2007.

36. Gay LR, Mills GE, Airasian PW. Educational Research: Competencies for Analysis and Applications, 10 ${ }^{\text {th }}$ Ed. Pearson Education, Inc. USA. 2011.

37. Martalina DS, Situmorang M, Sudrajat A. The Development of Innovative Learning Material with Integration of Project and Multimedia for the Teaching of Gravimetry, Advances in Social Science. Education and Humanities Research, $3^{\text {rd }}$ Annual International Seminar on Transformative Education and Educational Leadership. 2018;200:735-40.

38. Solomons TWG, Fryhle CB, Snyder SA. Organic Chemistry. John Wiley and Sons, Inc. USA. 2014.

39. Pedersen SF, Myers AF. Understanding the Principle of Organic Chemistry, a Laboratory Course. Brooks/Cole, Cengage Learning, Belmont, USA. 2011.

40. Straumanis A. Organic Chemistry, a Guided Inquiry. $2^{\text {nd }}$ Ed. Houghton Mifflin Harcourt Publishing Co., Boston. 2009.

41. Situmorang M, Sinaga M, Purba J, Daulay SI, Simorangkir M, Sitorus M, et al. Implementation of Innovative Chemistry Learning Material With Guided Tasks to Improve Students' Competence. J Balt Sci Educ. 2018;17(4):535-50.

42. Situmorang M, Sitorus M, Hutabarat W, Situmorang Z. The Development of Innovative Chemistry Learning Material for Bilingual Senior High School Students in Indonesia. Int Educ Stud. 2015;8(10):72-85.
43. Volmer D, Sepp K, Veski P, Raal A. The Implementation of Pharmacy Competence Teaching in Estonia. Pharmacy. 2017;5(2):18.

44. Cone C, Godwin D, Salazar K, Bond R, Thompson M, Myers O. Incorporation of an Explicit Critical-Thinking Curriculum to Improve Pharmacy Students' Critical-Thinking Skills. Am J Pharm Educ. 2016;80(3):41.

45. Ahn MS, Lee HE, Cheon KS, Joo HG. Ochang Chemical Safety Community, Son BS. Feasibility Evaluation of Designated Quantities for Chemicals Requiring Preparation for Accidents in the Korean Chemical Accident Prevention System. Int J Environ Res Public Health. 2020;17(6):1927.

46. Zwick M. The Design, Implementation and Assessment of an Undergraduate Neurobiology Course using a Project-Based Approach. J Undergrad Neurosci Educ. 2018;16(2):A131-42.

47. Cova TFGG, Pais AACC. Deep Learning for Deep Chemistry: Optimizing the Prediction of Chemical Patterns. Front Chem. 2019;7:809.

48. Straub J, Marsh RA, Whalen DJ. Small Spacecraft Development ProjectBased Learning Implementation and Assessment of an Academic Program. Springer International Publishing, Switzerland. 2017.

49. Zhou J, Zhou S, Huang C, Xu R, Zhang Z, Zeng S, et al. Effectiveness of problem-based learning in Chinese pharmacy education: A meta-analysis. BMC Med Educ. 2016;16(1):23.

50. Kızkapan O, Bektaş O. The Effect of Project Based Learning on Seventh Grade Students' Academic Achievement. Int J Instr. 2017;10(1):37-54.

51. Rifaioglu AS, Atas H, Martin MJ, Cetin-Atalay R, Atalay V, Doğan T. Recent applications of deep learning and machine intelligence on in silico drug discovery: methods, tools and databases. Brief Bioinform. 2019;20(5):1878-912.

52. Ma S, Kemmeren P, Aliferis CF, Statnikov A. An Evaluation of Active Learning Causal Discovery Methods for Reverse-Engineering Local Causal Pathways of Gene Regulation. Sci Rep. 2016;6:22558.

53. Cavanagh AJ, Aragón OR, Chen X, Couch A, Durham F, Bobrownicki A, et al. Student Buy-In to Active Learning in a College Science Course. CBE Life Sci Educ. 2016;15(4):ar76.

54. Hacisalihoglu G, Stephens D, Johnson L, Edington M. The use of an active learning approach in a SCALE-UP learning space improves academic performance in undergraduate General Biology. PLoS One. 2018;13(5):e0197916.

55. Rowe MP, Gillespie BM, Harris KR, Koether SD, Shannon LJ, Rose LA. Redesigning a General Education Science Course to Promote Critical Thinking. CBE Life Sci Educ. 2015;14(3):ar30.

56. Purba J, Situmorang M, Silaban R. The Development and Implementation of Innovative Learning Resource with Guided Projects for the Teaching of Carboxylic Acid Topic. Indian J Pharm Educ Res. 2019;53(4):603-12.

57. Sheng $\mathrm{T}, \mathrm{Hu}$ Q. Human Extracellular Superoxide Dismutase Recombination: A Project Based Learning Program in Biochemistry Designed for Nursing Students. Asian J Nur Edu Res. 2012;2(3):135-9.

58. Petersen JC, Judge L, Pierce DA. Conducting a Community-based Experiential-Learning Project to Address Youth Fitness. J Phys Educ Recreat Dance. 2012;83(6):30-6.

59. Rhodes C, Garrick J. Project-based learning and the limits of corporate knowledge. J Manag Educ. 2003;27(4):447-71.

60. Novak S, Shah S, Wilson JP, Lawson KA, Salzman RD. Pharmacy students' learning styles before and after a problem-based learning experience. Am J Pharm Educ. 2006;70(4):74.

61. Nainggolan B, Sitorus M, Hutabarat W, Situmorang M. Developing Innovative Chemistry Laboratory Workbook Integrated with Project-based Learning and Character-based Chemistry. Int J Instr. 2020;13(3):895-908. 
PICTORIAL ABSTRACT

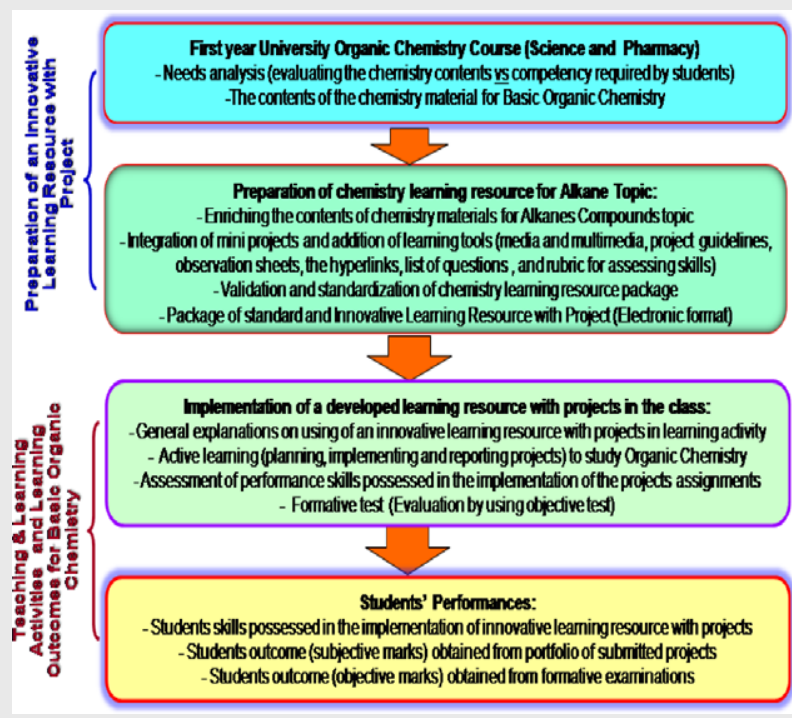

\section{SUMMARY}

An innovative learning package with projects has been developed to meet learning resources on teaching organic chemistry to chemistry and pharmacy students. The implementation of the learning unit has successfully utilized to facilitate active learning and improve performance in the field of organic chemistry. The research accomplished through the development of learning resource package with projects on the topic of Alkanes Compounds, the integration of media and multimedia into the project packages, followed by standardization to obtain adequate learning material for undergraduate students. The implementation of innovative learning resources has proven to be beneficial in helping students earning to learn the study of organic chemistry. Students are very enthusiastic about learning chemistry. Facilities available in learning resources help students to design and carry out project assignments. Research findings reveal that the developed learning package acts as a suitable learning resource to facilitate active learning in improving student performance on Organic Chemistry. Students have skillful skills and knowledge in the field of organic chemistry, which is shown from the score of knowledge and skills to meet the competencies in the field of chemistry. The learning resource model developed in this study can be adopted in other subjects to facilitate active learning in increasing knowledge and skills.

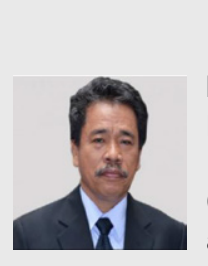

\section{About Authors}

Professor Manihar Situmorang: born 4 August 1960. He is a Professor at Department of Chemistry, Faculty of Mathematics and Natural Sciences, Universitas Negeri Medan, Medan, North Sumatera, INDONESIA. He has been teaching for more than 33 years. He was graduated from Dept. of Chemistry Education at Institute of Teacher Training Education Medan, INDONESIA (B.Sc. 1986), and from Dept. of Chemistry, The University of New South Wales (UNSW), Australia (Grad. Diploma 1989, M.Sc, 1992 and Ph.D, 2001). He is currently a Vice Rector on Planning, Collaboration and Communication Affairs at Universitas Negeri Medan, was a Dean in Faculty of Mathematic and Natural Sciences for 8 years, and Head of Research Institute for 4 years. His research interests are Sensor Development, Electroanalysis, Environmental, and Innovative Learning. His research interests are on Sensor Development, Electroanalysis, Environmental Study and Chemistry Education.

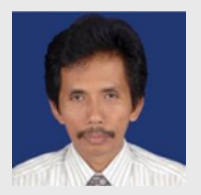

Jamalum Purba: born February 1964. He is currently a Ph.D student at Chemistry Education, Graduate Study Program, Universitas Negeri Medan, Medan, North Sumatera, INDONESIA. He was graduated from Dept. of Chemistry Education at Institute of Teacher Training Education Medan, INDONESIA (B.Sc. 1987), Dept. of Chemistry, Universitas Gajah Mada (M.Sc. 2001). He hold a position as a Lecturer in The Department of Chemistry Education, Universitas Negeri Medan since 1991. His research interests are on Organic Chemistry and Chemistry Education.

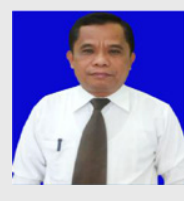

Professor Ramlan Silaban, born 18 June 1960. He is a Professor at Department of Chemistry, Faculty of Mathematics and Natural Science Universitas Negeri Medan, Medan, North Sumatera, INDONESIA. He was graduated from Dept. of Chemistry Education at Institute of Teacher Training Education Medan, INDONESIA (B.Sc. 1991), Master in Chemistry (M.Sc, 1991) and Doctor in Biochemistry (Ph.D, 1999) from Bandung Institute of Technology (ITB), Bandung, INDONESIA. He hold a position as Head of Chemistry Education, Graduate Study Program, Universitas Negeri Medan (2006 - 2019). His research interests are on Biochemistry and Chemistry Education.

Cite this article: Situmorang M, Purba J, Silaban R. Implementation of an Innovative Learning Resource with Project to Facilitate Active Learning to Improve Students' Performance on Chemistry. Indian J of Pharmaceutical Education and Research. 2020;54(4):905-14. 